\section{På veien mot å bli voksen}

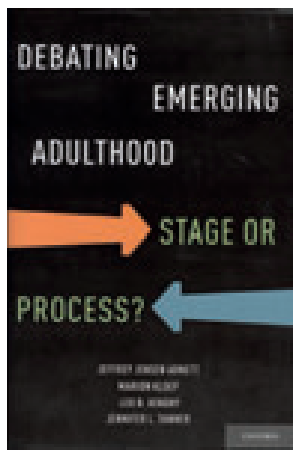

Jeffrey Jensen Arnett, Marion Kloep, Leo B. Hendry et al. Debating emerging adulthood Stage or process? 182 s, ill. Oxford: Oxford University Press, 2011. Pris GBP 23 ISBN 978-0-19-975717-6

Forfatterne er britiske og amerikanske psykologer. De opplyser ikke om målgruppene, men boken er av allmenn interesse. Hovedtemaet er overgangen fra ungdomstid til voksen alder. I tidligere teorier var stadietenkningen dominerende (Freud, Piaget, Erikson). Mellom ungdomstid og tidlig voksen alder var det ikke plass til noe stadium. Denne overgangsfasen var tidligere kort. Frem til 1950årene skjedde den i 19-20-årsalderen.

Fra omkring 1960 er det skjedd dramatiske endringer. Overgangsfasen er forlenget. Forandringene er størst for unge kvinner. Husmorrollen og morsrollen var fremtiden. Nå tar flere kvinner enn menn lang utdanning. Tidligere var 20 år alderen for å bli voksen, i dag er den nærmere 30.

Bakgrunnen er kravene og behovet for utdanning. Det har ført til dype holdningsendringer. Unge mennesker er ikke, og føler seg absolutt ikke, modne for arbeidslivet, og de ønsker ikke å bli voksne heller. «Det er ikke kult å bli voksen, det vil vi utsette lengst mulig.» Denne fasen er mulighetenes periode: man vil reise, ha opplevelser i fri utfoldelse og «alt er tillatt».

Det er store variasjoner, og beskrivelsene passer best på middelklassens byungdommer i vestlige land, og ikke på forholdene i utviklingsland og i jordbruksområder. Enhetlige teorier og forklaringsmodeller er av den grunn vanskelig å utvikle. Denne boken diskuterer forsøkene på å komme med teorier om denne overgangsfasen. De gamle teorier gjelder ikke lenger. Nye begreper dukker opp.

En av forfatterne, Jeffrey Jensen Arnett, har siden 2002 lansert begrepet «emerging adulthood» på denne forlengede overgangsfasen, perioden fra «the late teens through the twenties». Han fastholder de gamle synspunktene om stadier i utviklingen, og sammen med en annen av forfatterne, Jennifer L. Tanner, beskriver de hvorfor «emerging adulthood» representerer et stadium på veien mot å bli voksen.

De to andre redaktørene, Kloep og Hendry, aksepterer betegnelsen, men ser utviklingen som en prosess. Det er i tråd med «systemtenkingen» både i biologi og psykologi, der alle prosesser ses på som så komplekse at man må forlate ideen om enkle lineære forklaringer på årsak og virkning. Man må se på naturen som åpne systemer som består av og tilhører en rekke andre åpne systemer som alle påvirker hverandre. Deres viktigste motargument mot stadieinndelingen er at denne fasen ikke er universell, men gjelder bare begrensede grupper.

Som tittelen angir, er boken lagt opp som en diskusjon om disse to synspunktene, stadium eller prosess. Man kan spørre om dette er et godt utgangspunkt, men det er ikke tvil om at forfatterne har lyktes med å føre en interessant debatt både om «emerging adulthood» og om det skal oppfattes som et stadium eller en prosess. Leserne inviteres til å ta standpunkt. Slik gir den både fakta og innblikk i teoriutvikling.

Kilderegisteret er omfattende. Bokens form setter krav til leserens engasjement $\mathrm{i}$ problemstillingen, men temaet er så generelt at den vil være interessant for alle leger, men kanskje særlig for fastleger, pediatere, internister og psykiatere.

\section{Sverre Halvorsen}

Oslo

\section{Informativt om kreft - skrevet for våre pasienter}

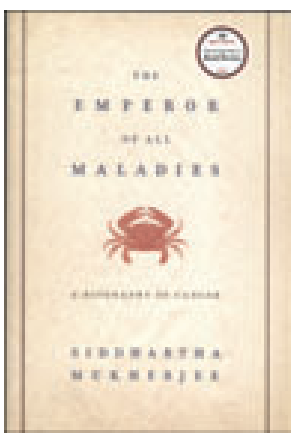

\author{
Siddhartha Mukherjee \\ The emperor of all maladies \\ A biography of cancer. 571 s, ill. \\ New York, NY: Scribner, 2010. Pris USD 30 \\ ISBN 978-1-4391-0795-9
}

Forfatteren, som er onkolog ved Columbia University, har gått løs på oppgaven å skrive kreftens dystre livshistorie for publikum i sin alminnelighet. Boken har vakt atskillig oppmerksomhet og ble av New York Times Book Magazine rangert blant de ti beste bøkene utgitt i 2010.

Forståelsen og behandlingen av kreftsykdom blir belyst i hovedsak ved å følge utviklingen av kjemoterapi ved leukemi. Kirurgisk onkologi omtales gjennom skiftende oppfatninger om behandling av brystkreft. Stråleterapi gis lite omtale. Med de utvalg som er gjort, har forfatteren lyktes med å gi et godt innblikk i forståelsen og behandlingen av kreft til ulike tider like frem til våre dager. Historien handler om vitenskapelig kreativitet og dristighet, men også om blindspor, konflikter og motarbeiding. Forfatteren belyser hvordan nyskapende samarbeid har gitt gode resultater fra en start basert på enkeltindivider som forente vitenskapelig nysgjerrighet med klinisk praksis. Leseren får innsikt i de nødvendige offer som pasientene har gjort underveis, for at det skulle være mulig å vinne ny kunnskap som etter hvert har brakt kreftbehandlingen dit vi er i dag.

Mukherjee skriver at vi kan kvitte oss med kreft bare i den grad vi kan frigjøre oss fra grunnleggende fysiologiske prosesser som vekst, aldring, regenerasjon, tilheling og reproduksjon. Kreft har økt i forekomst og som dødsårsak i den vestlige verden som følge av endring i sykdomspanorama og økende levealder, mens sykdommen i land med lite utviklet helsevesen ikke er blant de ti vanligste dødsårsakene. Han viser hvordan det var nødvendig å skape interesseorganisasjoner som kunne fungere som bindeledd mellom forskning og klinisk onkologi og helsepolitikk.

Mot slutten av boken er det gjort rede for hvordan molekylærbiologi og kreftgenetikk har åpnet nye behandlingsmuligheter i form av målrettet molekylær terapi. Kreftbehandlingens historie er kort og fylt av noen store nyvinninger og mange skuffelser. Forfatteren peker på at den gamle drømmen om å løse «kreftens gåte» en gang for alle ikke er realiserbar. Snarere dreier det seg om ustanselig videreutvikling for å forbli på det samme stedet, fordi kreftsykdommen endrer egenskaper som svar på behandling.

Temaene skifter mellom historie, anekdoter og vitenskapelig kunnskap på en måte som kan virke usystematisk. Forfatteren oppnår med det, og ved et betydelig fortellertalent, å fange leserens interesse og bygge opp en spenning som gjør boken lettlest uten at det går ut over det faglige innholdet. Det er 69 sider med noter og referanser med et omfattende register til slutt.

Dette er medisinsk journalistikk på høyt nivå. Dersom dette skal være kunnskapsnivået for våre pasienter, er det like greit å ha lest boken. Ingen er uberørt av temaet kreft. For helsepolitikere vil boken bidra med nøktern informasjon som kan være nyttig for fremtidige veivalg.

Hans H. Elverland

Norsk pasientskadeerstatning

Oslo 